\title{
NEOPLASIA
}

\section{Anticancer Drugs Induce Caspase-8/FLICE Activation and Apoptosis in the Absence of CD95 Receptor/Ligand Interaction}

\author{
By Sebastian Wesselborg, Ingo H. Engels, Evi Rossmann, Marek Los, and Klaus Schulze-Osthoff
}

\begin{abstract}
Proteases of the caspase family are the critical executioners of apoptosis. Their activation has been mainly studied upon triggering of death receptors, such as CD95 (Fas/ APO-1) and tumor necrosis factor-R1, which recruit caspase-8/FLICE as the most proximal effector to the receptor complex. Because apoptosis induced by anticancer drugs has been proposed to involve CD95/CD95 ligand interaction, we investigated the mechanism of caspase activation by daunorubicin, doxorubicin, etoposide, and mitomycin C. In J urkat leukemic T cells, all drugs induced apoptosis and the cleavage of procaspase-8 to its active p18 subunit. However, cells resistant to CD95 were equally susceptible to anticancer drugs and activated caspase-8 with a similar kinetic and dose response
\end{abstract}

$\mathbf{C}$ HEMOTHERAPEUTIC AGENTS kill cancer cells by multiple mechanisms, including intercalation into DNA, inhibition of DNA replication, cell membrane damage, or free radical generation. ${ }^{1,2}$ Although the primary intracellular targets of drug action are rather distinct, it has become evident that drug-induced cytotoxicity ultimately converges on a common pathway, causing apoptosis. Cells exposed to anticancer drugs display apoptotic alterations, such as cell shrinkage, chromatin condensation, and internucleosomal DNA fragmentation. ${ }^{3}$ A close link between apoptosis and the mechanism of drug action has been demonstrated by the involvement of similar genetic components. Overexpression of Bcl-2 proteins can confer drug resistance in transfected tumor cells. ${ }^{4-6}$ A number of investigations exposed a critical role of the tumor suppressor p53 in apoptosis after drug treatment. ${ }^{5,7,8}$ Finally, it has been recently shown that drug-induced cytotoxicity involves proteases of the caspase family, because specific inhibitors of caspases prevented cell death after treatment with different anticancer agents. ${ }^{9-12}$

Caspases are currently considered as the central executioners of many, if not all, apoptotic pathways. In mammalian cells, at least 12 different caspases exist, which are cysteine proteases that cleave their substrates after aspartate residues. ${ }^{13-15}$ Caspases are synthesized as inactive proenzymes that are proteolytically processed to form an active tetrameric complex composed of two heterodimeric subunits of about 10 and $20 \mathrm{kD}$. The activation mechanism of caspases is currently unknown and is an area of intense research. Activation may proceed through autoproteolysis of the precursor, through mutual processing, or by still undefined processes. An increasing number of proteins have been found to be cleaved by caspases, and for some of them an apoptotic function has been proposed. ${ }^{13-16}$ Among different substrates are enzymes involved in genome function, such as the DNA repair enzyme poly(adenosine diphosphateribose)polymerase (PARP) and DNA-dependent protein kinase (DNA-PK), or regulators of the cell cycle, including retinoblastoma protein, the $\mathrm{p} 53$ regulator MDM-2, MEKK, and protein kinase C- $\delta$. Substrates of the nucleus and cytoskeleton include lamins, Gas2, gelsolin, and fodrin. Furthermore, it has been found that DNA cleavage is triggered upon caspase-mediated as CD95-sensitive cells. The broad caspase inhibitor benzyloxycarbonyl-Val-Ala-Asp-fluoromethylketone prevented apoptosis and caspase-8 activation in response to CD95 and drug treatment, whereas a neutralizing CD95 decoy as well as a dominant-negative FADD construct selectively abrogated CD95, but not drug-induced effects. A potent activation of caspase-8 was also induced by cycloheximide, indicating that it was independent of protein synthesis. Our data, therefore, show that (1) anticancer drug-induced apoptosis does not require de novo synthesis of death ligands or CD95 interaction, and (2) that caspase- 8 can be activated in the absence of a death receptor signaling.

(C) 1999 by The American Society of Hematology.

degradation of the inhibitory subunit of a novel endonuclease, designated caspase-activated DNase. ${ }^{17}$

It is currently unknown why there are so many different caspases in mammalian cells. The most intensively studied member is caspase-3, which is activated by multiple apoptotic stimuli. Depletion of caspase- 3 through homologous recombination results in excessive accumulation of neuronal cells caused by a lack of apoptosis in the brain, whereas it has no affect in other tissues, indicating that caspase- 3 is redundant in many cell types. ${ }^{18}$ The physiologic relevance of the other members of the caspase family is also not well defined. Cells express more than one of these proteases, but whether all are functionally required for a single apoptotic pathway remains obscure. Current knowledge indicates that individual caspases have distinct substrate specificities, inhibitor profiles, and abilities to process each other. These findings suggest that caspases form a hierarchical network which, similar to the complement system, may function as an amplifier for a given apoptotic stimulus.

One of the best-defined apoptotic pathways is mediated by the surface receptor CD95 (APO-1/Fas). ${ }^{19-21}$ Triggering of the receptor by its natural ligand $\mathrm{CD} 95 \mathrm{~L}$ or agonistic antibodies induces the formation of a death-inducing signaling complex (DISC), which consists of the adapter protein FADD and FLICE/caspase-8. ${ }^{22-24}$ Complex formation is initiated through

From the Department of Internal Medicine I, Eberhard-KarlsUniversity, Tübingen, Germany.

Submitted June 18, 1998; accepted December 28, 1998.

Supported in part by grants from the Deutsche Forschungsgemeinschaft (SFB 364/A7) and the European Union Biomed-2 program. S.W. acknowledges a fellowship from the Bundesministerium für Bildung und Forschung.

Address reprint requests to Klaus Schulze-Osthoff, PhD, Department of Internal Medicine I, Eberhard-Karls-University, Otfried-Müller-Str. 10,D-72076 Tübingen, Germany; e-mail: schulze-osthoff@unituebingen.de.

The publication costs of this article were defrayed in part by page charge payment. This article must therefore be hereby marked "advertisement" in accordance with 18 U.S.C. section 1734 solely to indicate this fact.

(C) 1999 by The American Society of Hematology.

0006-4971/99/9309-0013\$3.00/0 
homophilic interaction of the death domains present in the intracellular part of both CD95 and FADD. FADD, in addition, contains a second interacting region, called the death effector domain (DED), which couples to caspase- 8 as the most proximal element in the caspase cascade. Further downstream in the death pathway, caspase- 8 presumably triggers the proteolytic activation of other caspases and cleavage of cellular substrates.

Although it is evident that different anticancer drugs ultimately mediate a common apoptotic pathway through the activation of caspases, the events occuring between primary target action of the drugs and the activation of apoptotic effectors are unclear. Recently, it has been proposed that drug-induced apoptosis occurs through the CD95 pathway. ${ }^{25-27}$ It has been observed that several anticancer drugs, such as doxorubicin, methotrexate, or bleomycin induce the upregulation of membrane CD95 and induction of CD95L expression, followed by the subsequent autocrine or paracrine induction of CD95-dependent apoptosis. Cell lines resistant to CD95 were found to be insensitive to anticancer drug-induced apoptosis. Furthermore, drug-induced apoptosis was prevented by CD95 neutralizing antibodies. However, there are also reports indicating that antitumor drugs may induce apoptosis by other pathways. ${ }^{28-32}$

In the present study, we investigated the mechanism of anticancer drug-induced apoptosis and the requirement of the CD95 system. We show that different antineoplastic drugs, such as daunorubicin, doxorubicin, etoposide, and mitomycin $\mathrm{C}$ induce caspase-dependent apoptosis to a similar extent in both CD95-sensitive and resistant leukemic $\mathrm{T}$ cells. Interestingly, caspase- 8 was activated in both cell types by these drugs and also by the protein synthesis inhibitor cycloheximide. Our data indicate that (1) anticancer drugs induce caspase-8 activation and apoptosis independent of CD95L/receptor interaction, and that (2) caspase- 8 can be activated in the absence of receptor signals even on inhibition of protein synthesis. Thus, these findings show that caspase-8, which has been previously regarded as the most proximal caspase in CD95 signaling, can be activated independently of death-receptor interaction.

\section{MATERIALS AND METHODS}

Cells and reagents. The human leukemic T-cell lines Jurkat and CEM were maintained in RPMI-1640 supplemented with $10 \%$ heatinactivated fetal calf serum (FCS), $100 \mathrm{U}$ of penicillin per milliliter, 0.1 $\mathrm{mg}$ streptomycin per milliliter, and $10 \mathrm{mmol} / \mathrm{L}$ HEPES (all from GIBCO-BRL, Eggenstein, Germany). Cells were grown at $37^{\circ} \mathrm{C}$ in a $5 \% \mathrm{CO}_{2}$ atmosphere and maintained in log phase. The CD95-resistant Jurkat subline, Jurkat-R, was generated by continuous culture in the presence of anti-CD95 monoclonal antibody (MoAb) $\left(\mathrm{IgG}_{3}, 1 \mu \mathrm{g} / \mathrm{mL}\right.$; Cell Diagnostica, Münster, Germany) for 6 months. HeLa cells stably transfected with a chimeric construct of a dominant-negative FADD mutant or the vector alone fused to green-fluorescent protein (GFP) were kindly provided by Dr P. Scheurich and Dr H. Wajant (University of Stuttgart, Stuttgart, Germany) $)^{33}$ and cultivated in RPMI-1640 supplemented with 5\% FCS, $10 \mathrm{mmol} / \mathrm{L}$ HEPES and antibiotics. The CD95-neutralizing chimeric protein glutathione-S transferase (GST) CD95, consisting of the extracellular part of CD95 fused to GST, was a gift from Dr E. Gulbins (University of Tübingen, Tübingen, Germany) and produced in Escherichia coli. The broad-range caspase inhibitor benzyloxycarbonyl-Val-Ala-Asp-fluoromethylketone (zVAD-fmk) was purchased from Enzyme Systems (Dublin, CA). The chemotherapeutic drugs daunorubicin, etoposide, and mitomycin $\mathrm{C}$ were obtained from the clinical pharmacy (Medical Clinics, Tübingen, Germany), and doxorubicin was purchased from Sigma (Deisenhofen, Germany). Daunorubicin and mitomycin $\mathrm{C}$ were dissolved in methanol and doxorubicin and etoposide in ethanol and kept as stock solutions at $-70^{\circ} \mathrm{C}$.

Measurement of cell death. For determination of cell death, $3 \times 10^{4}$ cells per well were seeded in microtiter plates and treated for 24 hours with the indicated concentrations of anti-CD95 or the chemotherapeutic agents. The leakage of fragmented DNA from apoptotic nuclei was measured by the method of Nicoletti et al. ${ }^{34}$ Briefly, apoptotic nuclei were prepared by lysing cells in a hypotonic lysis buffer ( $1 \%$ sodium citrate, $0.1 \%$ Triton $\mathrm{X}-100,50 \mu \mathrm{g} / \mathrm{mL}$ propidium iodide) and subsequently analyzed by flow cytometry. Nuclei to the left of the $2 \mathrm{~N}$ peak containing hypodiploid DNA were considered apoptotic. Phosphatidylserine externalization of apoptotic cells was visualized by staining with annexin-V-FITC after the manufacturer's protocol (BoehringerMannheim, Mannheim, Germany) and subsequent analysis in a flow cytometer by using the FSC/FL1 profile. Cell death was assessed by the uptake of propidium iodide ( $2 \mu \mathrm{g} / \mathrm{mL}$; Sigma) in phosphate-buffered saline (PBS) into nonfixed cells and subsequent flow cytometric analysis with the FSC/FL2 profile. All flow cytometry analyses were performed on a FACScalibur (Becton Dickinson, Heidelberg, Germany) by using CellQuest analysis software. Microscopic analysis of cell viability was performed with nonfixed GFP-FADD-DN expressing HeLa cells in an inverse fluorescent microscope.

Immunoblotting. Cleavage of PARP and caspase- 8 was detected by immunoblotting. In 24-well plates $1 \times 10^{6}$ cells were seeded and treated with the apoptotic stimuli. After the indicated periods, cells were washed in cold PBS and lysed in $1 \%$ Triton X-100, $50 \mathrm{mmol} / \mathrm{L}$ Tris, $\mathrm{pH}$ 7.6, and $150 \mathrm{mmol} / \mathrm{L} \mathrm{NaCl}$ containing $3 \mu \mathrm{g} / \mathrm{mL}$ aprotinin, $3 \mu \mathrm{g} / \mathrm{mL}$ leupeptin, $3 \mu \mathrm{g} / \mathrm{mL}$ pepstatin $\mathrm{A}$, and $2 \mathrm{mmol} / \mathrm{L}$ phenylmethylsulfonyl fluoride. Subsequently, proteins were separated under reducing conditions by $8 \%$ to $15 \%$ gradient sodium dodecyl sulfate-polyacrylamide gel electrophoresis and electroblotted to a polyvinylidene difluoride membrane (Amersham, Braunschweig, Germany). The loading and transfer of equal amounts of protein was confirmed by staining the membrane with Ponceau S. Membranes were blocked for 1 hour with 5\% nonfat dry milk powder in Tris-buffered saline (TBS: $10 \mathrm{mmol} / \mathrm{L}$ Tris- $\mathrm{HCl} \mathrm{pH} \mathrm{7.4,} 100 \mathrm{mmol} / \mathrm{L} \mathrm{NaCl}$ ) and then immunoblotted for 1 hour with rabbit anti-PARP polyclonal antibody $(1: 2,000$; BoehringerMannheim) or mouse anti-caspase-8 MoAb (1:10 dilution of a hybridoma supernatant; Cell Diagnostica). Membranes were washed four times with TBS $/ 0.05 \%$ Tween-20 and incubated with peroxidaseconjugated affinity-purified rabbit antimouse Ig for 1 hour. After extensive washing, the reaction was developed by enhanced chemiluminescent staining by using ECL reagents (Amersham).

\section{RESULTS}

Anticancer drug-induced apoptosis is independent of functional CD95/CD95L interaction. The mechanism by which antitumor drugs induce apoptosis remains controversial. It has been previously demonstrated that antineoplastic agents, such as doxorubicin, bleomycin, and methotrexate induce the expression of CD95L and elicit cell death by subsequent CD95 interaction. ${ }^{25-27}$ To investigate whether the inducible interaction of CD95L with its receptor is a prerequisite for drug-mediated apoptosis, we used the subclone Jurkat-R that had been selected for resistance to CD95 signaling. The dose response of druginduced apoptosis was assessed by flow cytometric staining of hypodiploid DNA in apoptotic nuclei. When CD95-sensitive Jurkat and CD95-resistant Jurkat-R cells were treated with mitomycin $\mathrm{C}$, both cell lines underwent apoptosis in a similar 
concentration-dependent manner (Fig 1A). When the CD95 pathway was stimulated by using agonistic anti-CD95 antibodies, cell death was induced up to a concentration of as low as 4 $\mathrm{ng} / \mathrm{mL}$ in Jurkat cells, whereas virtually no apoptosis was observed in the CD95-resistant cell line Jurkat-R (Fig 1B). To investigate whether chemotherapeutic drugs other than mitomycin C induce cell death independently of CD95, both cell lines were stimulated with daunorubicin, doxorubicin, and etoposide (Fig 2). Similar as in the previous experiment, all drugs induced cell death in Jurkat and Jurkat-R cells with almost the same dose dependency.

To further exclude a possible participation of CD95 in drug-mediated cell death, we preincubated cells with the neutralizing receptor decoy construct GST-CD95, which prevents CD95L from receptor binding. Induction of cell death was

A

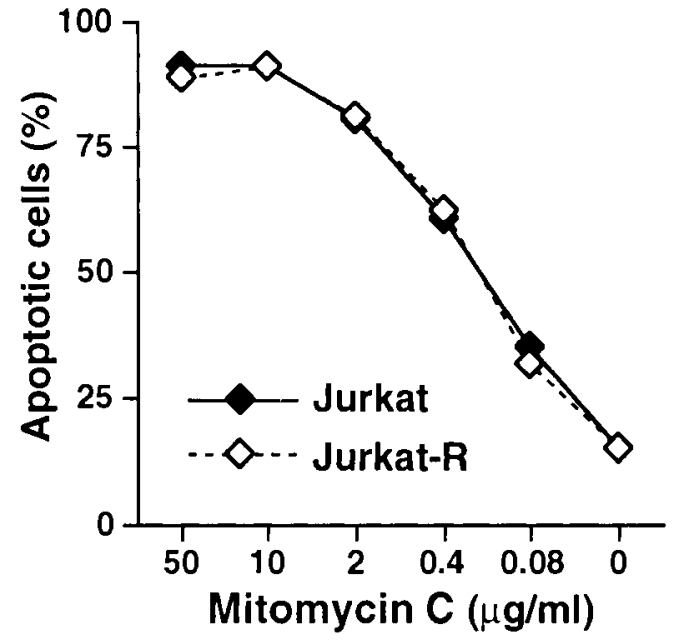

B

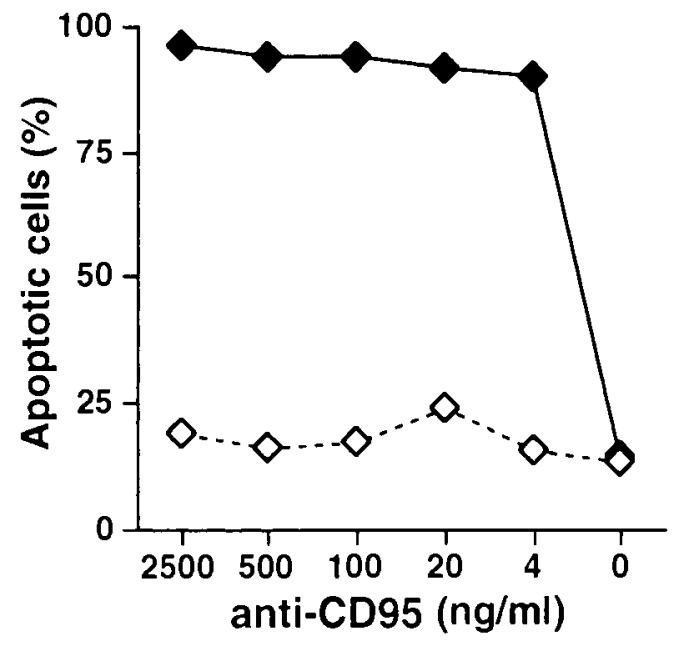

Fig 1. Effects of mitomycin C and anti-CD95 in CD95-sensitive and resistant J urkat cells. $3 \times 10^{4}$ CD95-sensitive $($ urkat;,---$)$ or resistant cells ( ) urkat-R; --., $\diamond$ ) were stimulated with (A) mitomycin C or (B) agonistic anti-CD95 antibodies at the indicated concentrations for $\mathbf{2 4}$ hours. Cells in the absence of apoptotic stimuli were treated with the diluent of the respective highest drug concentration. Induction of apoptosis was assessed by propidium iodide staining of hypodiploid apoptotic nuclei and subsequent flow cytometry.
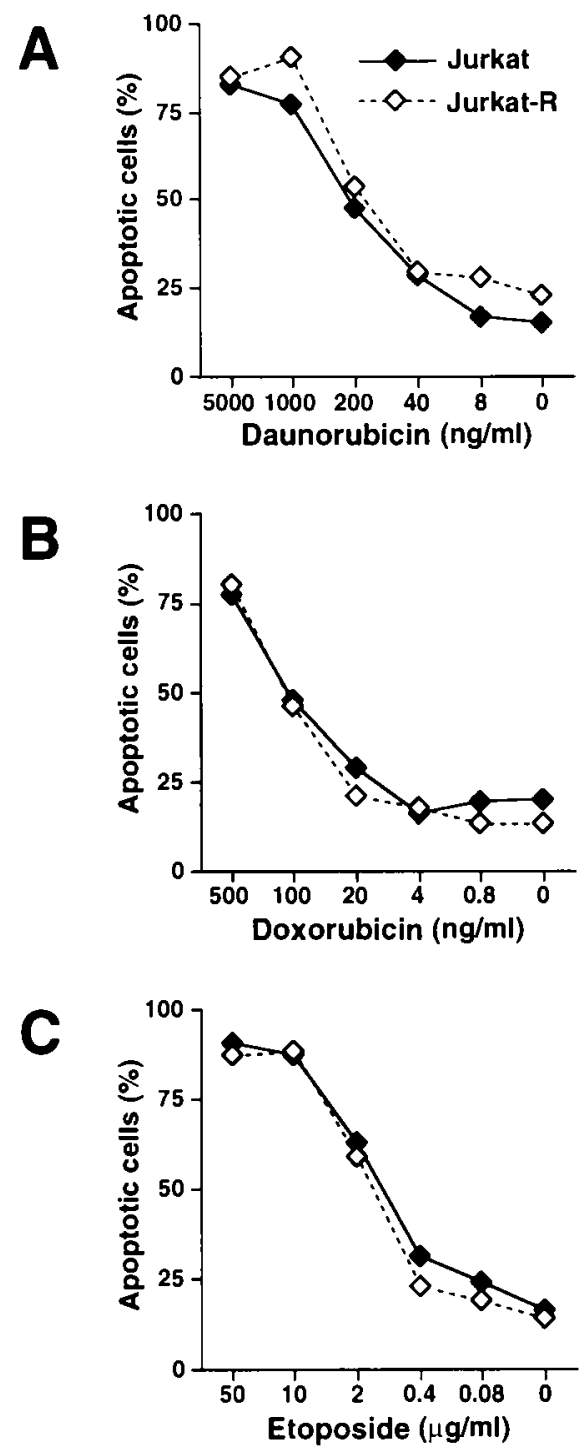

Fig 2. Induction of apoptosis mediated by daunonubicin, doxorubicin, and etoposide is independent of CD95 receptor signaling. J urkat $(--, \diamond)$ or J urkat-R cells $(--, \diamond)$ were stimulated with (A) daunorubicin, (B) doxorubicin, and (C) etoposide at the indicated concentrations. Assessment of hypodiploid apoptotic nuclei was performed as described in Fig 1.

assessed in a flow cytometer by annexin-V-FITC staining. As shown in Fig 3A, all antitumor agents induced apoptosis in both Jurkat as well as in Jurkat-R cells, whereas anti-CD95-triggered apoptosis occurred only in Jurkat cells. GST-CD95 inhibited anti-CD95-triggered cell death, whereas apoptosis elicited by the anticancer drugs was virtually unaffected (Fig 3B). GST alone, which was used as a negative control, had no effect on anti-CD95 nor on drug-mediated cell death (Fig 3C). Similar data were obtained by fluorescence-activated cell sorter analysis using propidium iodide staining of dead cells and apoptotic nuclei (data not shown). Thus, these results suggest that signaling through CD95 is not a prerequisite for anticancer drug-mediated apoptosis. 


\section{A) Medium}

B) GST-CD95

\section{C) GST}

\section{Jurkat \\ Jurkat-R}
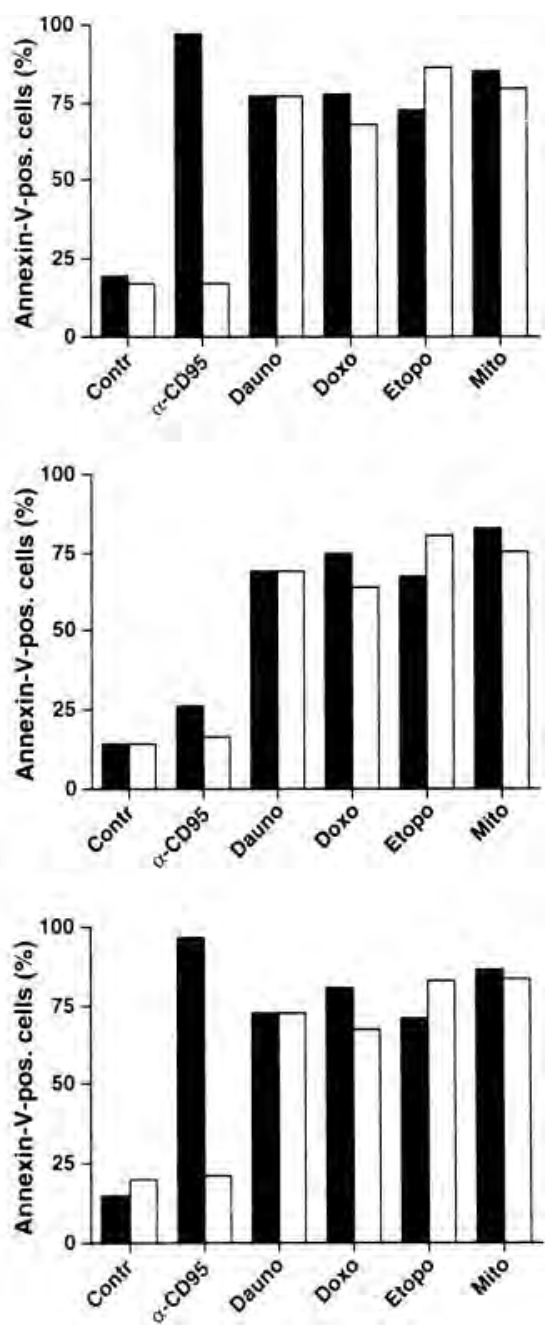

Fig 3. Inhibition of CD95 signaling does not affect antitumor drug-mediated cell death. J urkat (E) or J urkat-R $(\square)$ cells $\left(3 \times 10^{4}\right.$ per well) were preincubated with (A) medium, (B) GST-CD95 (100 $\mu \mathrm{g} /$ $\mathrm{mL})$, or (C) GST (100 $\mu \mathrm{g} / \mathrm{mL})$ for 1 hour, and then treated with either anti-CD95 (20 ng/mL), daunorubicin (Dauno; $5 \mu \mathrm{g} / \mathrm{mL}$ ), doxorubicin (Doxo; $1 \mu \mathrm{g} / \mathrm{mL}$ ), etoposide (Etopo; $25 \mu \mathrm{g} / \mathrm{mL}$ ), or mitomycin C (Mito; $25 \mu \mathrm{g} / \mathrm{mL}$ ). Apoptosis was assessed after 24 hours by measuring phosphatidylserine exposure by annexin-V-FITC-staining and flow cytometry.

Caspases are involved in induction of apoptosis by mitomycin $C$, etoposide, daunorubicin, and doxorubicin. Because caspases are involved in drug-mediated apoptosis, we investigated whether caspases are also activated by anticancer drugs in the absence of CD95/CD95L interaction. Therefore, we stimulated CD95-sensitive and resistant cells under conditions analogous as in Fig 3 and used zVAD-fmk, a broad peptide inhibitor of caspases. Similarly, as in the previous experiment, all cytotoxic agents induced cell death in both Jurkat and Jurkat-R cells, whereas CD95 triggering only resulted in apoptosis in Jurkat cells. Flow cytometric staining of hypodiploid nuclei revealed that zVAD-fmk strongly attenuated anti-CD95 and drug-induced apoptosis (Fig 4A, upper panel). Inhibition of caspases was also able to prevent membrane damage and cell death as determined by measuring the uptake of propidium iodide into cells (Fig 4A, lower panel).

We further investigated the involvement of caspases in drug-induced cell death by measuring cleavage of a known caspase substrate in immunoblot analyses. PARP, an enzyme involved in DNA repair, is cleaved during apoptosis and has been shown to serve as a substrate for caspase-3. ${ }^{35,36}$ Fig 4B shows that PARP, a $116-\mathrm{kD}$ protein, was cleaved into the characteristic $89-\mathrm{kD}$ fragment after 8 hours of daunorubicin treatment in both CD95-sensitive and resistant Jurkat cells (Fig 4B). Etoposide also induced PARP cleavage in a dosedependent manner in both cell lines (Fig 4C). Thus, these data show that caspases are involved in drug-mediated apoptosis independently of CD95L/receptor interaction.

Caspase-8/FLICE is activated by anticancer drugs in the absence of CD95L/receptor interaction. During CD95mediated apoptosis, the caspase cascade is initiated by the recruitment and cleavage of caspase- 8 at the DISC. Because anticancer drugs obviously mediate activation of caspases independently of CD95, we next investigated whether caspase-8 is activated during drug-induced cell death. Caspase- 8 is synthesized as two isoforms of about $55 \mathrm{kD}$ (caspase-8a and caspase-8b) which, after formation of intermediate cleavage products of 43 and $41 \mathrm{kD}$, are processed to a p18 and p10 heterodimer. ${ }^{37,38}$ As assessed with an antibody directed against the p18 subunit, CD95 ligation resulted in the cleavage of procaspase- 8 into its characteristic intermediate fragments and the active p18 subunit (Fig 5A). Surprisingly, a similar cleavage pattern was obtained after treatment of Jurkat cells with etoposide (Fig 5A), indicating that caspase- 8 was also activated by a receptor-independent apoptotic pathway.

A time course experiment revealed that after CD95 ligation of sensitive Jurkat cells caspase- 8 was readily processed into the p43/41 intermediate forms within 1 hour, whereas no processing was observed in CD95-resistant Jurkat-R cells (Fig $5 B)$. Doxorubicin and daunorubicin induced caspase- 8 cleavage in a similar kinetic after 8 to 12 hours in both Jurkat and Jurkat-R cells (Figs 5B and C). In contrast, etoposide and mitomycin $\mathrm{C}$-induced caspase- 8 activation occurred slightly faster. After treatment with etoposide significant caspase- 8 activation was observed within 5 hours, whereas mitomycin $\mathrm{C}$ induced full processing after 8 hours (Fig 5C). In addition, a dose-response experiment showed that all anticancer drugs induced proteolytic activation of caspase- 8 at concentrations that are achievable in the plasma of patients during therapy (Fig 6).

Inhibition of CD95L/receptor interaction does not affect drug-mediated caspase- 8 activation. We further analyzed the effect of the neutralizing GST-CD95 fusion protein on caspase-8 activation after drug treatment. Whereas GST-CD95 potently blocked cleavage of caspase-8 in response to anti-CD95 (Fig $7 \mathrm{~A}$ ) or recombinant CD95L (data not shown), it had virtually no effect on the processing of caspase- 8 accomplished by etoposide or mitomycin C in CD95-sensitive and resistant Jurkat T-cells. GST, which was used as a control, did not affect the processing of caspase-8. In contrast to GST-CD95, the caspase inhibitor zVAD-fmk blocked not only anti-CD95, but also etoposide and mitomycin C-induced cleavage of caspase- 8 . Essentially, the same results were obtained in leukemic CEM 
Fig 4. Anticancer drugs mediate caspase-dependent apoptosis in the absence of CD95 signaling. (A) CD95-susceptible J urkat or CD95-resistant J urkat-R cells were pretreated with medium $(\square$ and $\mathbb{Q})$ or 100 $\mu \mathrm{mol} / \mathrm{L}$ zVAD-fmk $(\square)$ for 1 hour, and subsequently stimulated with anti-CD95 (20 ng/ $\mathrm{mL})$, daunorubicin (Daun; $5 \mu \mathrm{g} / \mathrm{mL}$ ), doxorubicin (Doxo; $1 \mu \mathrm{g} / \mathrm{mL}$ ), etoposide (Etop; $25 \mu \mathrm{g} / \mathrm{mL}$ ), or mitomycin C (Mito; 25 $\mu \mathrm{g} / \mathrm{mL}$ ). After 24 hours, induction of apoptosis was measured by propidium iodide staining of hypodiploid nuclei (upper panel) and cell death was determined by the uptake of propidium iodide in dead cells (lower panel). (B and C) stimulated were $1 \times 10^{6}$ J urkat or J urkat-R cells for the indicated time with (B) daunorubicin $(5 \mu \mathrm{g} / \mathrm{mL})$ or with (C) different concentrations of etoposide $(25 \mu \mathrm{g} / \mathrm{mL}$ lanes 4,8 ; $12.5 \mu \mathrm{g} / \mathrm{mL}$ lanes 3,$7 ; 6.25 \mu \mathrm{g} / \mathrm{mL}$ lanes 2,6 or diluent control lanes 1,5) for 6 hours. Cellular proteins were resolved on a $8 \%$ to $15 \%$ sodium dodecyl sulfatepolyacrylamide gel electrophoresis (SDS-PAGE) and caspase activity was detected by cleavage of the caspase-specific substrate PARP by using immunoblot analysis. Filled arrowheads (4) indicate the uncleaved p116 and open arrowheads $(\triangleleft)$ indicate the cleaved p89 form of PARP.
A
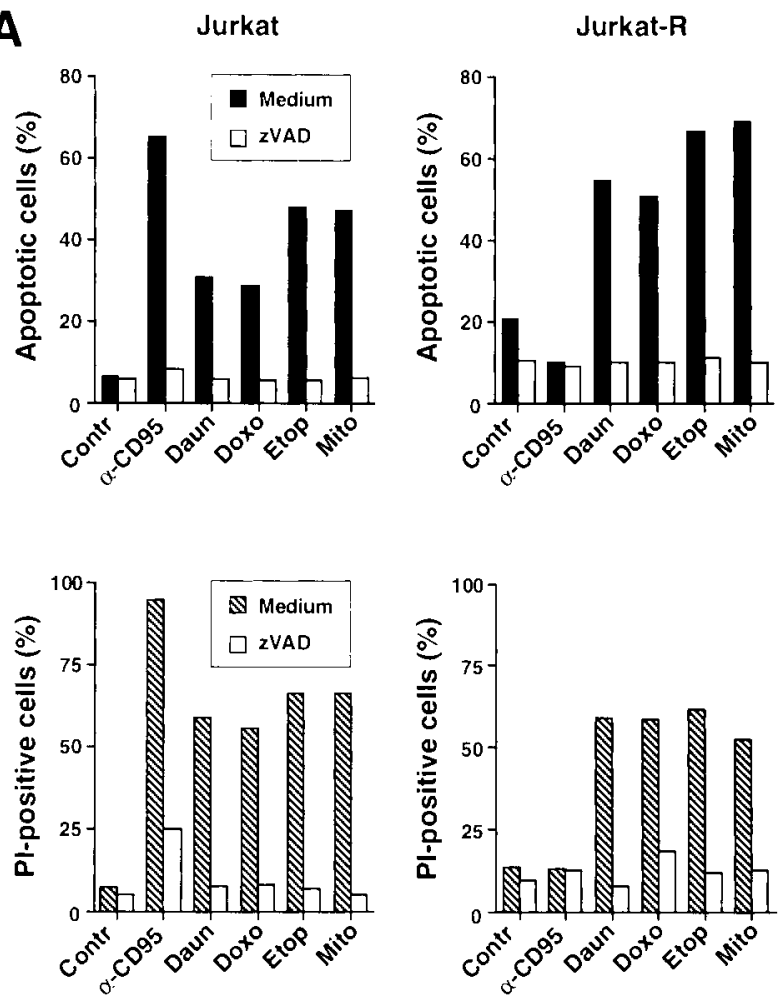

B

Dauno

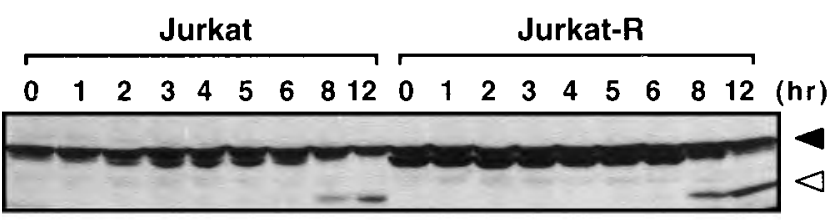

Immunoblot: anti-PARP

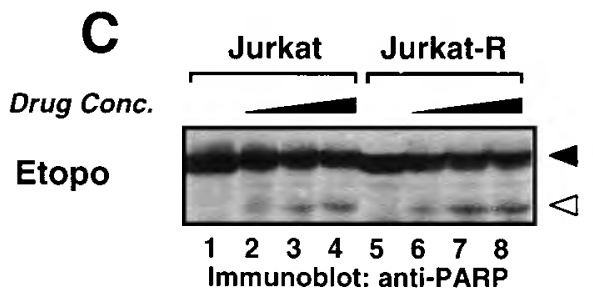

recruited to the DISC of CD95, but also to the receptors for tumor necrosis factor (TNF) and TNF-related apoptosisinducing ligand (TRAIL). To further exclude a potential role of death receptors in drug-mediated activation of caspase-8, we analyzed the effect of anticancer drugs in HeLa cells, which stably expressed a GFP-tagged dominant-negative mutant of the adapter protein FADD lacking the essential DED region. ${ }^{33}$ It has been shown that FADD transduces apoptotic signals triggered by CD95, TNF-R1 and the TRAIL receptors..$^{22,33,39-43}$ In accordance, HeLa-FADD-DN cells are resistant to anti-CD95 and TRAIL and have an intrinsic resistance to TNF-mediated apoptosis. ${ }^{33}$ Microscopic analysis revealed that stimulation with anti-CD95 did not induce any apoptotic alterations in HeLa- 
A

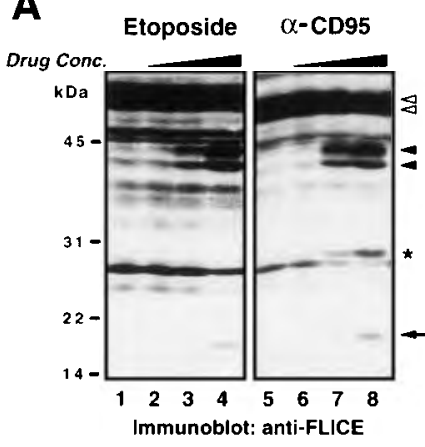

B

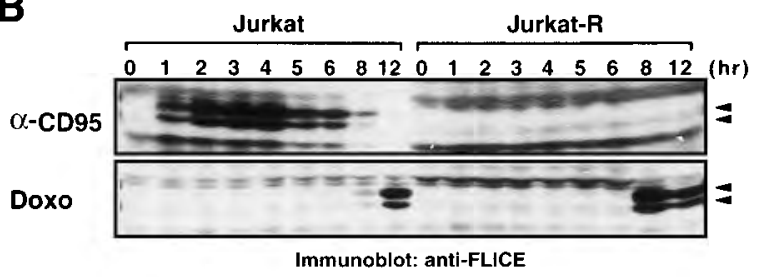

C

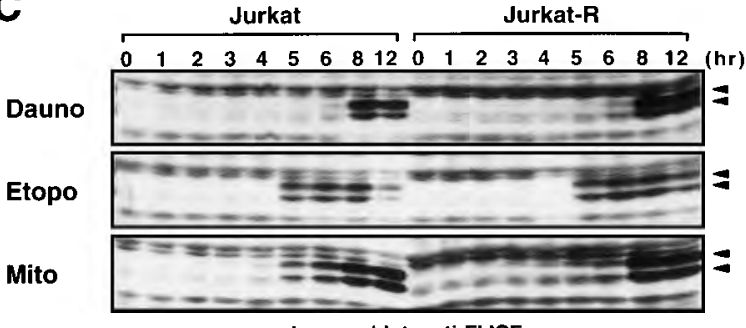

Immunoblot: anti-FLICE

Fig 5. Chemotherapeutic agents induce processing of caspase- 8 in the absence of CD95 signaling. (A) J urkat cells $\left(1 \times 10^{6}\right)$ were treated with different concentrations of either etoposide $(50 \mu \mathrm{g} / \mathrm{mL}$ lane $4 ; 5 \mu \mathrm{g} / \mathrm{mL}$ lane 3; $0.5 \mu \mathrm{g} / \mathrm{mL}$ lane 2; diluent control lane 1$)$ for 6 hours or anti-CD95 $(1,000 \mathrm{ng} / \mathrm{mL}$ lane $8 ; 50 \mathrm{ng} / \mathrm{mL}$ lane 7; $2.5 \mathrm{ng} / \mathrm{mL}$ lane 6; diluent control lane 5) for 3 hours. Cellular proteins were separated by SDS-PAGE and processing of procaspase-8 was detected by immunoblotting with anti-caspase-8. Open arrowheads $(\triangleleft)$ indicate the two different isoforms of procaspase-8 (caspase-8/a and caspase-8/b) that are cleaved into the intermediate forms p43 and p41 ( 4 ) and finally processed to the active p18 subunit $(\leftarrow)$. Ig light chain of stimulatory anti-CD95 antibody is indicated with an asterisk. (B) J urkat or J urkat-R cells $\left(1 \times 10^{6}\right)$ were treated for the indicated time with anti-CD95 (1 $\mu \mathrm{g} / \mathrm{mL}$ ), doxorubicin (Doxo; $1 \mu \mathrm{g} / \mathrm{mL}$ ), or (C) with daunorubicin (Dauno; $5 \mu \mathrm{g} / \mathrm{mL}$ ), etoposide (Etopo; 20 $\mu \mathrm{g} / \mathrm{mL}$ ), or mitomycin C (Mito; $25 \mu \mathrm{g} / \mathrm{mL}$ ). Cellular proteins were immunoblotted with anti-caspase-8 as described in (A). Only a section of the immunoblots indicating the cleaved intermediate forms ( $p 43$ and p41) of caspase-8a and caspase-8b is shown.

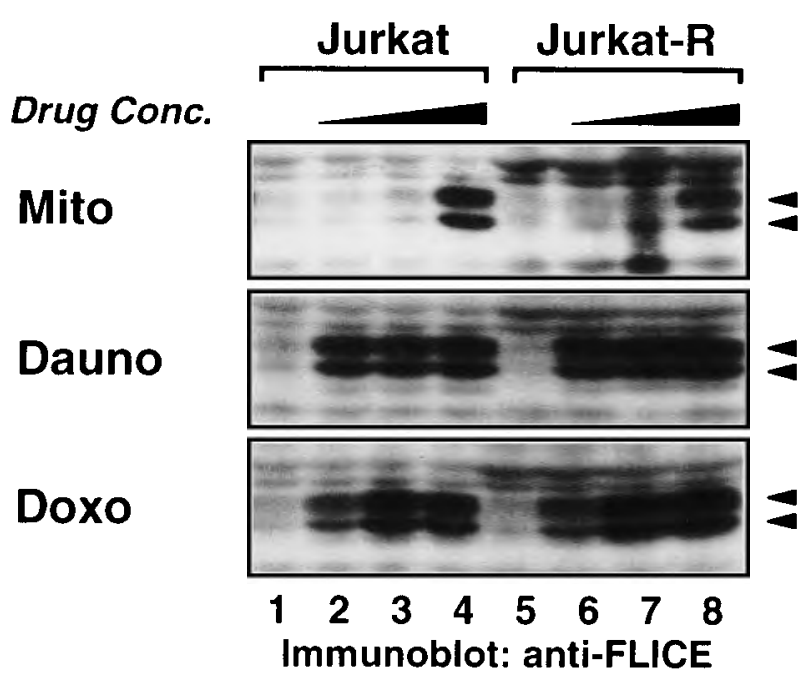

Fig 6. Dose-dependent cleavage of caspase-8 by mitomycin $C$, daunorubicin, and doxorubicin. J urkat and J urkat-R cells $\left(1 \times 10^{6}\right)$ were stimulated with mitomycin C (25 $\mu \mathrm{g} / \mathrm{mL}$ lanes 4,$8 ; 12.5 \mu \mathrm{g} / \mathrm{mL}$ lanes 3,7; $6.25 \mu \mathrm{g} / \mathrm{mL}$ lanes 2,6; diluent control lanes 1,5; for 6 hours), daunorubicin $(5 \mu \mathrm{g} / \mathrm{mL}$ lanes 4,8; $2.5 \mu \mathrm{g} / \mathrm{mL}$ lanes 3,7; $1.25 \mu \mathrm{g} / \mathrm{mL}$ lanes 2,6; diluent control lanes 1,5; for 10 hours) or doxorubicin (2 $\mu \mathrm{g} / \mathrm{mL}$ lanes 4,8; $1 \mu \mathrm{g} / \mathrm{mL}$ lanes 3,7; $0.5 \mu \mathrm{g} / \mathrm{mL}$ lanes 2,6; diluent control lanes 1,5; for 10 hours). Whole cell lysates were immunoblotted with anti-caspase-8 as described in Fig $\mathbf{5 A}$. Filled arrowheads (4) indicate the cleaved intermediate forms of caspase-8a and caspase-8b.
FADD-DN cells, thus confirming the protective effect of the dominant-negative FADD-mutant (Fig 8A). In contrast, treatment with staurosporine and mitomycin $\mathrm{C}$ caused the appearance of typical apoptotic features such as cell condensation and membrane blebbing (Fig 8A). The parallel assessment of DNA fragmentation revealed that all cytotoxic drugs induced apoptosis in both HeLa-FADD-DN and vector control cells, whereas anti-CD95 induced apoptosis only in HeLa cells transfected with the vector alone (Fig 8B). In accordance, staurosporine and mitomycin-C activated caspase- 8 in both HeLa-vector and HeLa-FADD-DN cells, whereas anti-CD95 triggered activation of caspase-8 only in HeLa-vector cells (Fig 8C). These data indicate that apoptosis by anticancer drugs does not require death receptor signaling and that caspase- 8 can be activated in the absence of a FADD-containing receptor signaling complex.

Inhibition of protein synthesis by cycloheximide activates caspase-8. Because the family of death receptors is steadily growing, it could not be excluded that the activation of caspase- 8 by antitumor drugs is mediated by yet unknown death receptors that transduce their signals independently of FADD. Therefore, we asked whether de novo synthesis of other death ligands, such as TNF or TRAIL, is involved in drug-induced caspase- 8 activation. To this end, cells were treated with cycloheximide, an inhibitor of protein synthesis. In some cell types, the sole inhibition of translation by cycloheximide induces apoptosis. This apoptosis is independent on CD95 signaling and occurred to a similar extent in both Jurkat and Jurkat-R cells (Fig 9A). Interestingly, treatment with cycloheximide also induced processing of caspase- 8 in the absence of any additional stimuli in CD95 sensitive and resistant cells (Fig 9B). 


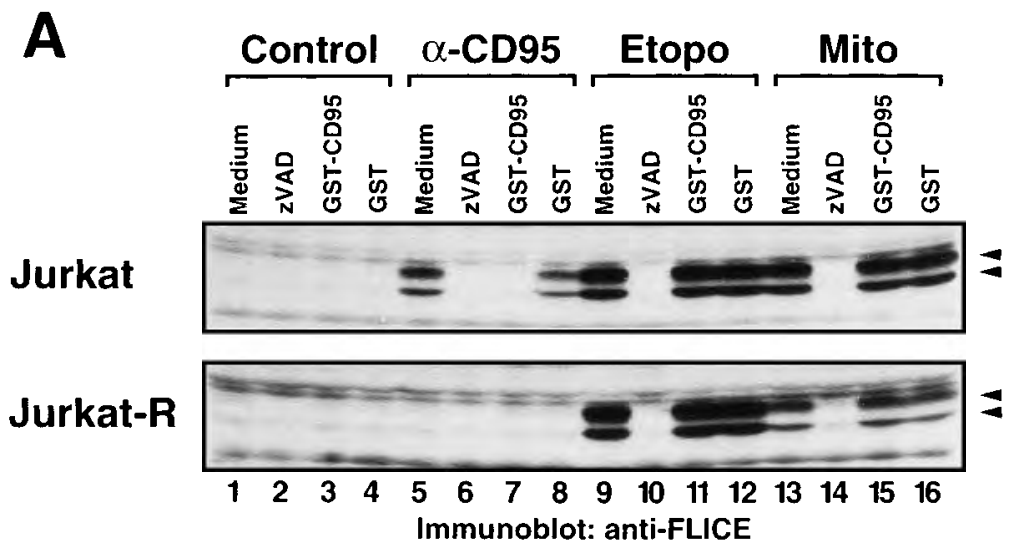

Fig 7. Inhibition of CD95 signaling with GST-CD95

\section{B}

does not inhibit antitumor drug-mediated cleavage of caspase-8 and PARP. (A) J urkat, J urkat-R cells $\left(1 \times 10^{6}\right)$ or (B) CEM cells were pretreated with medium, ZVAD-fimk (100 $\mu \mathrm{mol} / \mathrm{L})$, GST-CD95 (100 $\mu \mathrm{g} / \mathrm{mL})$, or GST $(100 \mu \mathrm{g} / \mathrm{mL})$ for 1 hour, and then stimulated with anti-CD95 ( $20 \mathrm{ng} / \mathrm{mL} ; 3$ hours), etoposide (Etopo; $25 \mu \mathrm{g} / \mathrm{mL} ; 6$ hours) and mitomycin C (Mito; $25 \mu \mathrm{g} / \mathrm{mL}$; 6 hours) or medium (6 hours). Cellular proteins were immunoblotted with (A and B) anti-caspase-8 or (B) anti-PARP as described in Fig 5A. The immunoblots indicate the cleaved intermediate fragments ( 4 ) of caspase-8a and caspase-8b. The anti-PARP immunoblot shows the uncleaved p116 and the cleaved p89 form of PARP (४).

\section{CEM}

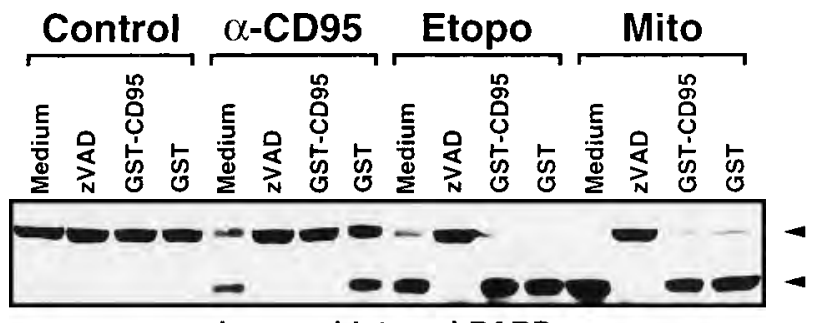

Immunoblot: anti-PARP

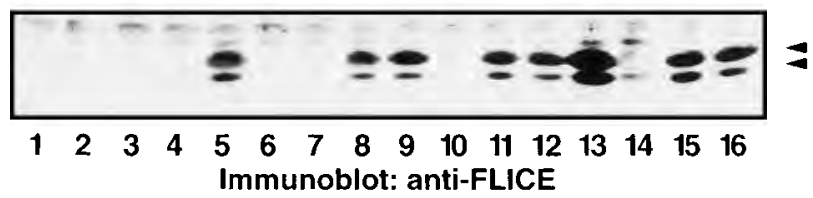

These data finally exclude that inducible expression of CD95L or other death ligands is an indispensable prerequisite for the activation of caspase- 8 and subsequent apoptosis.

\section{DISCUSSION}

In the present study, we investigated the mechanism of cell death induced by a number of anticancer agents. We show that daunorubicin, doxorubicin, mitomycin $\mathrm{C}$ as well as etoposide induce caspase-dependent apoptosis in drug-sensitive target cells. This suggests that drug-induced cytotoxicity is mediated by mechanisms that take place downstream of primary intracellular target action. These data are in line with previous results by us and others showing that effector caspases, such as caspase- $3,-6$, and -7 are critically involved in anticancer drug-mediated cell death. ${ }^{9-12}$

For the first time, it is shown that antineoplastic agents used in conventional chemotherapy are also able to induce activation of caspase-8. Previously, the role of caspase- 8 appeared to be restricted to apoptosis mediated by death receptors, such as CD95, TNF-R1, and the TRAIL receptors. In the death receptor pathway, caspase- 8 is a crucial component of the DISC, in which it is recruited through its DEDs that interact with receptor-associated FADD. ${ }^{22-24,44}$ Because caspase- 8 , with the exception of caspase-10, is the only DED-containing protease, it is assumed to act as a proximal initiator caspase, which subsequently processes downstream effector caspases.

The activation of caspase- 8 by anticancer drugs, as shown in

this study, could be explained by the notion that drug-induced cytotoxicity might be mediated by a death receptor-dependent mechanism. Accordingly, it was recently proposed that anticancer drugs induce the upregulation of CD95L by ceramidemediated mechanism, which then induces subsequent CD95dependent apoptosis in drug-sensitive target cells. ${ }^{25-27,45}$ However, our present data convincingly show that this pathway may not be a principle and necessary mechanism of anticancer drug action. This assumption is supported by a number of independent evidences.

First, we show that anticancer drugs induce apoptosis in both CD95-sensitive and resistant Jurkat cells with a similar kinetic and dose dependency. Second, although both anticancer drugand CD95-induced apoptosis was prevented by a broad-range caspase inhibitor, only CD95-mediated cell death was inhibitable by a neutralizing CD95 receptor decoy construct in leukemic Jurkat and CEM cells. Third, the occurrence of drug-induced apoptosis in HeLa cells stably transfected with a dominant-negative FADD mutant excludes the possibility that other FADD-dependent death receptors are involved in anticancer drug-mediated cell death. Finally, we show that caspase- 8 activation and subsequent apoptosis can also be induced by cycloheximide, an inhibitor of protein synthesis. Although this latter finding does not exclude that the release of a preformed death ligand may be involved, it suggests that inducible synthesis of CD95L or other ligands is not a prerequisite for drug-induced caspase- 8 activation and apoptosis. 
A
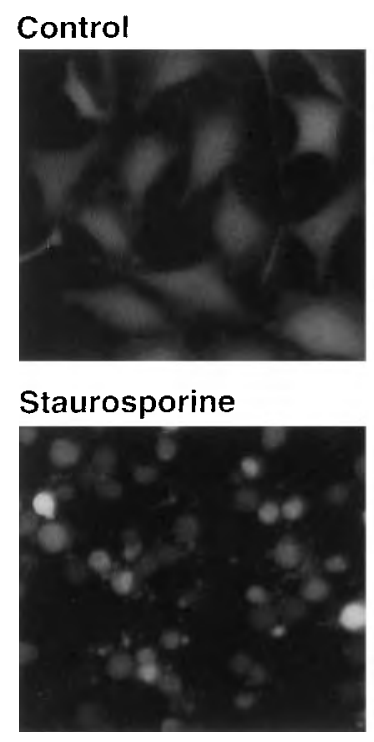

\section{anti-CD95}

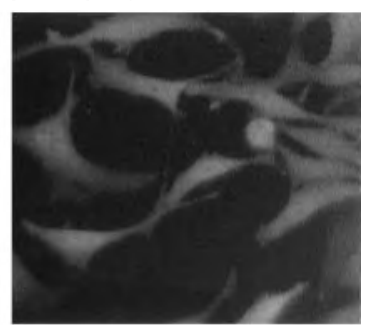

Mitomycin C

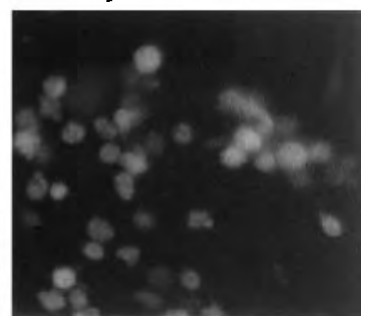

B

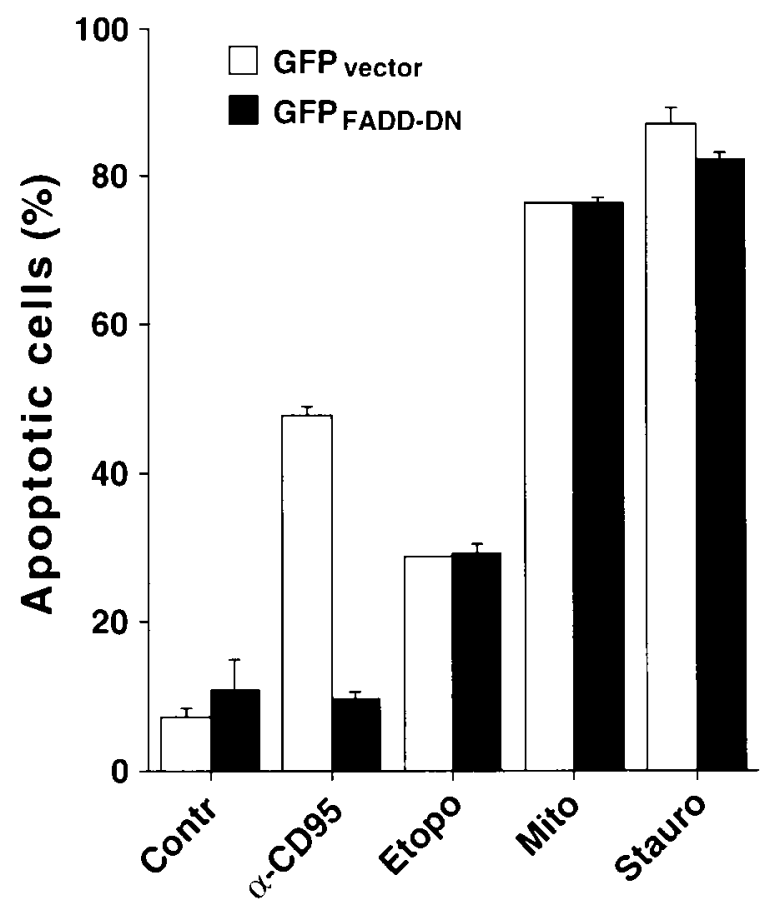

C

HeLa vector

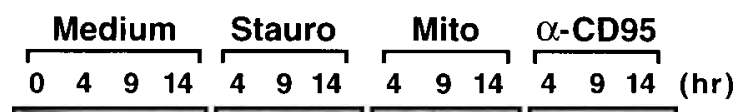

HeLa FADD-DN
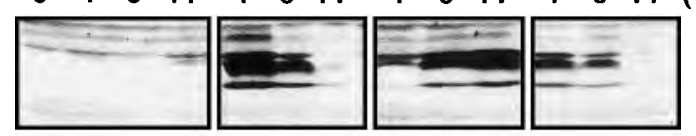

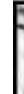
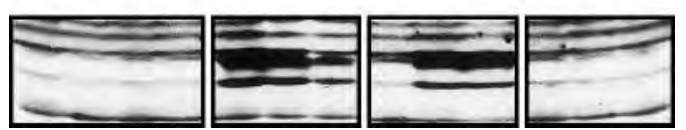

Immunoblot: anti-FLICE

Fig 8. Drug-induced apoptosis and activation of caspase-8 is independent of FADD signaling. (A and B) HeLa cells $\left(4 \times 10^{4}\right)$ stably expressing a GFP-tagged dominant-negative mutant of FADD (GFP FADD-DN $_{\text {) }}$ or the GFP-tagged vector alone (GFP vector) were treated with anti-CD95 (1 $\left.\mu \mathrm{g} / \mathrm{mL}\right)$, staurosporine ( $2.5 \mu \mathrm{mol} / \mathrm{L})$, etoposide $(25 \mu \mathrm{g} / \mathrm{mL})$, mitomycin C $(25 \mu \mathrm{g} / \mathrm{mL})$ or left untreated. (A) After 24 hours, HeLa-FADD-DN cells were analyzed for the induction of apoptosis under a fluorescent microscope. (B) Subsequently, HeLa-FADD-DN and HeLa-vector cells were lysed in a hypotonic buffer, and the number of hypodiploid apoptotic nuclei was determined in a flow cytometer. Mean values of \pm SD from triplicate experiments are shown. (C) HeLa-FADD-DN $\left(1.5 \times 10^{6}\right)$ or HeLa-vector cells were incubated with medium, anti-CD95 $(1 \mu \mathrm{g} / \mathrm{mL})$, staurosporine $(2.5 \mu \mathrm{mol} / \mathrm{L})$ or mitomycin C $(25 \mu \mathrm{g} / \mathrm{mL})$ for the indicated time. Cellular proteins were immunoblotted with anti-caspase-8 as described in Fig $5 \mathrm{~A}$. The intermediate cleavage forms (p43 and p41) of caspase-8a and caspase-8b are shown.

The mechanism of caspase- 8 processing and activation independently of CD95 is intriguing. Besides the death receptor/ FADD pathway, it has become recently clear that a second, either independent or interconnected pathway exists, which is essentially controlled by the release of mitochondrial components and inhibited by antiapoptotic members of the Bcl-2 family. ${ }^{46-51}$ An early event in this process is the redistribution of cytochrome c into the cytosol, which can be triggered by a variety of apoptotic conditions such as death receptors, ceramide, and anticancer drugs. $48,49,51-53$ In the cytosol, cytochrome $\mathrm{c}$ interacts, together with dATP, with apoptotic proteaseactivating factor-1 (Apaf-1), the mammalian homologue of the Caenorhabditis elegans cell death regulator Ced-4. ${ }^{54}$ Binding of these components then exposes an interaction motif in Apaf-1, which serves as a so-called caspase recruitment domain (CARD) by binding to caspases that have a similar CARD motif at their $\mathrm{N}$-terminus. A CARD motif has been identified in caspase-1, -2 , and $-9 .{ }^{55}$ Caspase- 8 and the structurally related caspase- 10 also contain a long prodomain that may exert a similar regulatory function. In this respect, it has been found that caspase- 8 can interact with Ced-4 in cell-free systems. ${ }^{56}$ Therefore, it is possible that caspase- 8 is either directly recruited to Apaf- 1 or activated by an upstream caspase of this cascade. It will be interesting to investigate whether caspase- 8 is activated by direct interaction with Apaf-1 or further downstream by another protease such as caspase- 9 . 
A

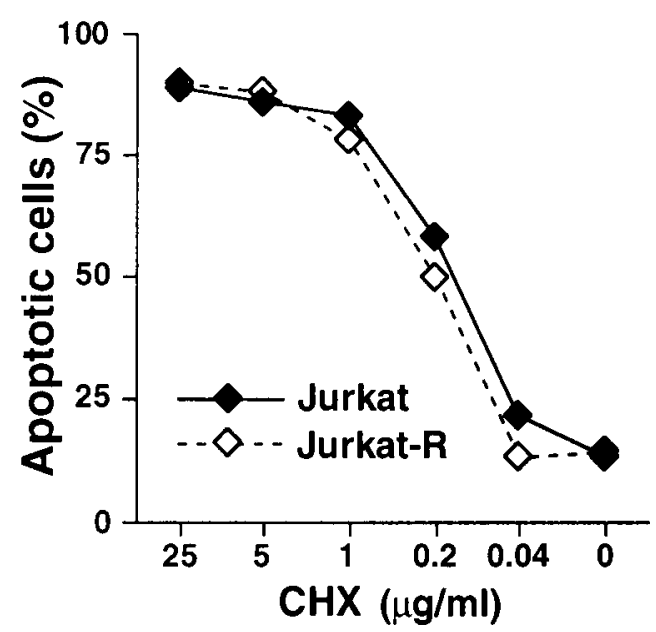

$\mathbf{B}$

Drug Conc. $\mathrm{CHX}$

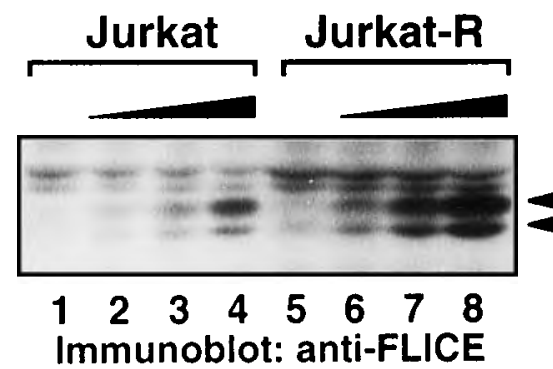

Fig 9. Inhibition of protein synthesis by cycloheximide induces apoptosis and processing of caspase-8. (A) J urkat $\left(3 \times 10^{4}\right)(\$)$ or $J$ urkat-R cells $(\diamond)$ were treated with the indicated concentrations of cycloheximide for $\mathbf{2 4}$ hours. Assessment of apoptotic nuclei was accomplished by flow cytometry of propidium iodide-stained hypodiploid nuclei. (B) J urkat or J urkat-R cells $\left(1 \times 10^{6}\right)$ were incubated with cycloheximide (lanes 4,8: $10 \mu \mathrm{g} / \mathrm{mL}$; lanes 3,7: $2 \mu \mathrm{g} / \mathrm{mL}$; lanes 2,6: 0.4 $\mu \mathrm{g} / \mathrm{mL}$; lanes 1,5: diluent control) for 5 hours. Total cell lysates were immunoblotted with anti-caspase-8 antibody as described in Fig 5A. Filled arrowheads ( 4 ) indicate the cleaved intermediate forms of 43 $k D$ and 41 kD of caspase-8a and caspase-8b.

There are also other evidences supporting the idea that anticancer drug-induced and CD95-induced apoptosis involve distinct proximal effector pathways. It has been observed that Bcl-2 and Bcl- $\mathrm{X}_{\mathrm{L}}$, which exert their antiapoptotic function at mitochondria, could potently inhibit anticancer drug-induced cell death, whereas CD95-mediated or TNF-R1-mediated apoptosis was not affected. ${ }^{11,57,58}$ In addition, recent gene targeting showed that FADD-deficient fibroblasts became resistant to apoptosis mediated by several death receptors, although these cells remained sensitive to anticancer drug treatment. ${ }^{59}$ In line with this, we found that expression of a dominant/negative FADD construct in HeLa cells interfered with CD95-drug induced but not anticancer-drug induced apoptosis. This further suggests that a FADD-independent pathway of drug-induced apoptosis is not restricted to Jurkat T cells.

Overall, understanding the mechanisms of anticancer druginduced apoptosis is of principal importance for developing effective strategies in tumor therapy. It has been suggested that CD95L is responsible for maintaining the immunoprivilege of some organs. ${ }^{60,61}$ Although the role of CD95 in immunoprivilege is controversially discussed, ${ }^{62-64}$ this would mean that drug-triggered CD95L expression would be consequently associated with a loss of immunosurveillance induced by drugresistant tumor cells bearing CD95L. However, the present data clearly show that apoptosis mediated by anticancer drugs does not necessarily require a functional CD95 system. Although anticancer drugs and CD95 ligation converge at a common downstream pathway, both pathways can act independently to induce apoptosis in sensitive target cells.

\section{ACKNOWLEDGMENT}

We thank Dr E. Gulbins for kindly providing us with the GST-CD95 construct and Dr P. Scheurich and Dr H. Wajant for HeLa cells stably transfected with GFP-FADD-DN.

\section{REFERENCES}

1. Barry MA, Behnke CA, Eastman A: Activation of programmed cell death (apoptosis) by cisplatin, other anticancer drugs, toxin and hyperthermia. Biochem Pharmacol 40:2353, 1990

2. Hannun YA: Apoptosis and the dilemma of cancer chemotherapy. Blood 89:1845, 1997

3. Fisher DE: Apoptosis in cancer therapy: Crossing the threshold. Cell 78:539, 1994

4. Miyashita T, Reed JC: Bcl-2 oncoprotein blocks chemotherapyinduced apoptosis in a human leukemia cell line. Blood 81:151, 1993

5. Lotem J, Sachs L: Regulation by bcl-2, c-myc, and p53 of susceptibility to induction of apoptosis by heat shock and cancer chemotherapy compounds in differentiation-competent and a defective myeloid leukemic cells. Cell Growth Differ 4:41, 1993

6. Yang E, Korsmeyer SJ: Molecular thanatopsis: A discourse on the BCL2 family and cell death. Blood 88:386, 1996

7. Lowe SW, Ruley HE, Jacks T, Housman DE: p53-dependent apoptosis modulates the cytotoxicity of anticancer agents. Cell 74:957, 1993

8. Strasser A, Harris AW, Jacks T, Cory S: DNA damage can induce apoptosis in proliferating lymphoid cells via p53-independent mechanisms inhibitable by Bcl-2. Cell 79:329, 1994

9. Zhu H, Fearnhead HO, Cohen GM: An ICE-like protease is a common mediator of apoptosis induced by diverse stimuli in human monocytic THP.1 cells. FEBS Lett 374:303, 1995

10. Chen Z, Naito M, Mashima T, Tsuruo T: Activation of actincleavable interleukin $1 \beta$-converting enzyme (ICE) family protease CPP-32 during chemotherapeutic agent-induced apoptosis in ovarian carcinoma cells. Cancer Res 56:5224, 1996

11. Datta R, Banach D, Kojima H, Talanian RV, Alnemri ES, Wong WW, Kufe DW: Activation of the CPP32 protease in apoptosis induced by $1-\beta$-D-arabinofuranosylcytosine and other DNA-damaging agents. Blood 88:1936, 1996

12. Los M, Herr I, Friesen C, Fulda S, Schulze-Osthoff K, Debatin KM: Cross-resistance of CD95- and drug-induced apoptosis as a consequence of deficient activation of caspases (ICE/Ced-3 proteases). Blood 90:3118, 1997

13. Cohen GM: Caspases: The executioners of apoptosis. Biochem J 326:1, 1997

14. Nicholson DN, Thornberry NA: Caspases: Killer proteases. Trends Biochem Sci 22:299, 1997

15. Cryns V, Yuan J: Proteases to die for. Genes Dev 12:1551, 1998

16. Stroh C, Schulze-Osthoff K: Death by a thousand cuts: an ever increasing list of caspase substrates. Cell Death Differ 5:997, 1998

17. Enari M, Sakahiera H, Yokoyama H, Okawa K, Iwamatsu A, 
Nagata S: A caspase-activated DNase that degrades DNA during apoptosis, and its inhibitor ICAD. Nature 391:43, 1998

18. Kuida K, Zheng TS, Na S, Kuan C, Yang D, Karasuyama H, Rakic P, Flavell RA: Decreased apoptosis in the brain and premature lethality in CPP32-deficient mice. Nature 384:368, 1996

19. Krammer PH, Dhein J, Walczak H, Behrmann I, Mariani S, Matiba B, Fath M, Daniel PT, Knipping E, Westendorp MO, Stricker K, Baumler C, Hellbrandt S, Germer M, Peter ME, Debatin KM: The role of APO-1-mediated apoptosis in the immune system. Immunol Rev 142:175, 1994

20. Schulze-Osthoff K, Ferrari D, Los M, Wesselborg S, Peter ME: Apoptosis signaling by death receptors. Eur J Biochem 254:439, 1998

21. Nagata S: Apoptosis by death factor. Cell 88:355, 1997

22. Boldin MP, Goncharov TM, Goltsev YV, Wallach D: Involvement of MACH, a novel MORT1/FADD-interacting protease, in Fas/APO-1- and TNF receptor-induced cell death. Cell 85:803, 1996

23. Kischkel FC, Hellbardt S, Behrmann I, Germer M, Pawlita M, Krammer PH, Peter ME: Cytotoxicity-dependent APO-1 (Fas/CD95)associated proteins form a death-inducing signaling complex (DISC) with the receptor. EMBO J 14:5579, 1995

24. Muzio M, Chinnaiyan AM, Kischkel FC, O'Rourke K, Shevchenko A, Ni J, Scaffidi C, Bretz JD, Zhang M, Gentz R, Mann M, Krammer PH, Peter ME, Dixit VM: FLICE, a novel FADD-homologous ICE/CED-3-like protease, is recruited to the CD95 (Fas/APO-1) death-inducing signaling complex. Cell 85:817, 1996

25. Friesen C, Herr I, Krammer PH, Debatin KM: Involvement of the CD95 (APO-1/FAS) receptor/ligand system in drug-induced apoptosis in leukemia cells. Nat Med 2:574, 1996

26. Müller M, Strand S, Hug H, Heinemann E-M, Walczak H, Hofmann WJ, Stremmel W, Krammer PH, Galle PR: Drug-induced apoptosis in hepatoma cells is mediated by the CD95 (Apo-1/Fas) receptor/ligand system and involves activation of wild-type p53. J Clin Invest 99:403, 1997

27. Fulda S, Sieverts H, Friesen C, Herr I, Debatin KM: The CD95 (APO-1/Fas) system mediates drug-induced apoptosis in neuroblastoma cells. Cancer Res 57:3823, 1997

28. Eischen CM, Kottke TJ, Martins LM, Basi GS, Tung JS, Earnshaw WC, Leibson PJ, Kaufmann SH: Comparison of apoptosis in wild-type and Fas-resistant cells: Chemotherapy-induced apoptosis is not dependent on Fas/Fas ligand interactions. Blood 90:935, 1997

29. Gamen S, Anel A, Lasierra P, Alava MA, Martinez Lorenzo MJ, Pineiro A, Naval J: Doxorubicin-induced apoptosis in human T-cell leukemia is mediated by caspase-3 activation in a Fas-independent way. FEBS Lett 417:360, 1997

30. Villunger A, Egle A, Kos M, Hartmann BL, Geley S, Kofler R, Greil R: Drug-induced apoptosis is associated with enhanced Fas (Apo-1/CD95) ligand expression but occurs independently of Fas (Apo-1/CD95) signaling in human T-acute lymphatic leukemia cells. Cancer Res 57:3331, 1997

31. Fulda S, Friesen C, Los M, Scaffidi C, Mier W, Benedict M, Nunez G, Krammer PH, Peter ME, Debatin KM: Betulinic acid triggers CD95 (APO-1/Fas)- and p53-independent apoptosis via activation of caspases in neuroectodermal tumors. Cancer Res 57:4956, 1997

32. Tolomeo M, Dusonchet L, Meli M, Grimaudo S, D'Alessandro N, Papoff G, Ruberti G, Rausa L: The CD95/CD95 ligand system is not the major effector in anticancer drug-mediated apoptosis. Cell Death Differ 5:735, 1998

33. Wajant H, Johannes FJ, Haas E, Siemienski K, Schwenzer R, Schubert G, Weiss T, Grell M, Scheurich P: Dominant-negative FADD inhibits TNFR60-, Fas/Apo1- and TRAIL-R/Apo2-mediated cell death but not gene induction. Curr Biol 8:113, 1998

34. Nicoletti I, Migliorati G, Pagliacci MC, Grignani F, Riccardi C: A rapid and simple method for measuring thymocyte apoptosis by propidium iodide staining and flow cytometry. J Immunol Methods 139:271, 1991
35. Kaufmann SH, Desnoyers S, Ottaviano Y, Davidson NE, Poirier GG: Specific proteolytic cleavage of poly(ADP-ribose) polymerase: An early marker of chemotherapy-induced apoptosis. Cancer Res 53:3976, 1993

36. Tewari M, Quan LT, O'Rourke K, Desnoyers S, Zeng Z, Beidler DR, Poirier GG, Salvesen GS, Dixit VM: Yama/CPP32 $\beta$, a mammalian homolog of CED-3, is a CrmA-inhibitable protease that cleaves the death substrate poly(ADP-ribose) polymerase. Cell 81:801, 1995

37. Medema JP, Scaffidi C, Kischkel FC, Shevchenko A, Mann M, Krammer PH, Peter ME: FLICE is activated by association with the CD95 death-inducing signaling complex (DISC). EMBO J 16:2794, 1997

38. Scaffidi C, Medema JP, Krammer PH, Peter ME: FLICE is predominantly expressed as two functionally active isoforms, caspase8/a and caspase-8/b. J Biol Chem 272:26953, 1997

39. Chinnaiyan AM, O'Rourke K, Yu GL, Lyons RH, Garg M, Duan DR, Xing L, Gentz R, Ni J, Dixit VM: Signal transduction by DR3, a death domain-containing receptor related to TNFR-1 and CD95. Science 274:990, 1996

40. Pan G, O'Rourke K, Chinnaiyan AM, Gentz R, Ebner R, Ni J, Dixit VM: The receptor for the cytotoxic ligand TRAIL. Science 276:111, 1997

41. Walczak H, Degli Esposti MA, Johnson RS, Smolak PJ, Waugh JY, Boiani N, Timour MS, Gerhart MJ, Schooley KA, Smith CA, Goodwin RG, Rauch CT: TRAIL-R2: A novel apoptosis-mediating receptor for TRAIL. EMBO J 16:5386, 1997

42. Chaudhary PM, Eby M, Jasmin A, Bookwalter A, Murray J, Hood L: Death receptor 5, a new member of the TNFR family, and DR4 induce FADD-dependent apoptosis and activate the NF- $\mathrm{BB}$ pathway. Immunity 7:821, 1997

43. Schneider P, Thome M, Burs K, Bodmer JL, Hofman K, Kataoka T, Holler N, Tschopp J: TRAIL receptors 1 (DR4) and 2 (DR5) signal FADD-dependent apoptosis and activate NF-кB. Immunity 7:831, 1997

44. Pan G, Ni J, Wei YF, Yu G, Gentz R, Dixit VM: An antagonist decoy receptor and a death domain-containing receptor for TRAIL. Science 277:815, 1997

45. Herr I, Wilhelm D, Bohler T, Angel P, Debatin KM: Activation of CD95 (APO-1/Fas) signaling by ceramide mediates cancer therapyinduced apoptosis. EMBO J 16:6200, 1998

46. Strasser A, Harris AW, Huang DC, Krammer PH, Cory S: Bcl-2 and Fas/APO-1 regulate distinct pathways to lymphocyte apoptosis. EMBO J 14:6136, 1995

47. Smith KG, Strasser A, Vaux DL: CrmA expression in $T$ lymphocytes of transgenic mice inhibits CD95 (Fas/APO-1)-transduced apoptosis, but does not cause lymphadenopathy or autoimmune disease. EMBO J 15:5167, 1996

48. Kluck RM, Bossy Wetzel E, Green DR, Newmeyer DD: The release of cytochrome $\mathrm{c}$ from mitochondria: a primary site for $\mathrm{Bcl}-2$ regulation of apoptosis. Science 275:1132, 1997

49. Yang J, Liu X, Bhalla K, Kim CN, Ibrado AM, Cai J, Peng TI, Jones DP, Wang X: Prevention of apoptosis by Bcl-2: release of cytochrome c from mitochondria blocked. Science 275:1129, 1997

50. Newton K, Harris AW, Bath ML, Smith KGC, Strasser A: A dominant interfering mutant of FADD/MORT1 enhances deletion of autoreactive thymocytes and inhibits proliferation of mature T lymphocytes. EMBO J 17:706, 1998

51. Scaffidi C, Fulda S, Srinivasan A, Friesen C, Li F, Tomaselli KJ, Debatin K-M, Krammer P, Peter ME: Two CD95 (Apo-1/Fas) signaling pathways. EMBO J 17:1675, 1998

52. Adachi S, Cross AR, Babior BM, Gottlieb RA: Bcl-2 and the outer mitochondrial membrane in the inactivation of cytochrome $\mathrm{c}$ during Fas-mediated apoptosis. J Biol Chem 272:21878, 1997

53. Kharbanda S, Pandey P, Schofield L, Israels S, Roncinske R, Yoshida K, Bharti A, Yuan Z-M, Saxena S, Weichselbaum R, Nalin C, Kufe D: Role of Bcl- $\mathrm{x}_{\mathrm{L}}$ as an inhibitor of cytosolic cytochrome C 
accumulation in DNA damage-induced apoptosis. Proc Natl Acad Sci USA 94:6939, 1997

54. Zou H, Henzel WJ, Liu X, Lutschg A, Wang X: Apaf-1, a human protein, homologous to C. elegans Ced-4, participates in cytochrome c-dependent activation of caspase-3. Cell 90:405, 1997

55. Hofmann K, Bucher P, Tschopp J: The CARD domain: a new apoptotic signalling motif. Trends Biochem Sci 22:155, 1997

56. Chinnaiyan AM, O'Rourke K, Lane BR, Dixit VM: Interaction of CED-4 with CED-3 and CED-9: A molecular framework for cell death. Science 275:1122, 1997

57. Moreno MB, Memon SA, Zacharchuk CM: Apoptosis signaling pathways in normal T cells: Differential activity of Bcl-2 and IL-1 $\beta$ converting enzyme family protease inhibitors on glucocorticoid- and Fas-mediated cytotoxicity. J Immunol 157:3845, 1996

58. Erhardt P, Cooper GM: Activation of the CPP32 apoptotic protease by distinct signaling pathways with differential sensitivity to Bcl- $x_{\mathrm{L}}$. J Biol Chem 271:17601, 1996

59. Yeh WC, Pompa JL, McCurrach ME, Shu HB, Elia AJ, Shahinian A, Ng M, Wakeham A, Khoo W, Mitchell K, El-Deiry WS,
Lowe SW, Goeddel DV, Mak TW: FADD: Essential for embryo development and signaling from some, but not all, inducers of apoptosis. Science 279:1954, 1998

60. Bellgrau D, Gold D, Selawry H, Moore J, Franzusoff A, Duke RC: A role for CD95 ligand in preventing graft rejection. Nature 377:630, 1995

61. Griffith TS, Brunner T, Fletcher SM, Green DR, Ferguson TA: Fas ligand-induced apoptosis as a mechanism of immune privilege. Science 270:1189, 1995

62. Seino K, Kayagaki N, Okumura K, Yagita H: Antitumor effect of locally produced CD95 ligand. Nat Med 3:165, 1997

63. Allison J, Georgiou HM, Strasser A, Vaux DL: Transgenic expression of CD95 ligand on islet $\beta$-cells induces a granulocytic infiltration but does not confer immune privilege upon islet allografts. Proc Natl Acad Sci USA 94:3943, 1997

64. Kang SM, Schneider DB, Lin Z, Hanahan D, Dichek DA, Stock OG, Baekkeskov S: Fas ligand expression in islets of Langerhans does not confer immune privilege and instead targets them for rapid destruction. Nat Med 3:738, 1997 